\title{
Analysis of Mother's Anxiety Level with Compliance to Visit to Integrated Service Post in the Covid-19 Pandemic at the Tangkiang Public Health Center
}

\author{
Kurniawan Edi Priyanto, Sitti \\ Ramlah Mardjan \\ STRADA Indonesia Institute of \\ Health Science, Indonesia \\ Email: \\ kedipriyanto@gmail.com
}

Received : October $4^{\text {nd }} 2021$

Accepted : October $15^{\text {rd }} 2021$

Published : November $27^{\text {th }} 2021$

\begin{abstract}
Background : The low achievement of toddler visits during the pandemic to the Tangkiang Integrated Service Post was $20 \%$ due to the mother's anxiety when bringing her toddler to the Integrated Service Post during the covid 19 pandemic, the mother of the toddler was afraid of the child and herself being infected by covid 19 when she came to visit the Integrated Service Post.

Purpose : The purpose of this study was to analyze the level of mother's anxiety with the compliance of toddlers' visits to the Integrated Service Post during the Covid 19 pandemic at the Tangkiang Public Health Center, Kintom District, Banggai Regency.

Methods : This study uses a correlational analytic design with a cross sectional approach. The population in this study were 30 respondents with a total sample of 30 respondents. sampling in this study using total sampling technique. Data collection using questionnaires and $\mathrm{MCH}$ handbooks. Data analysis to see the relationship between the independent variable and the dependent variable using the chi square statistical test with a significant level of $=0.05$.

Results : The results showed that of the 30 respondents, half of the respondents experienced a mild level of anxiety, namely 15 respondents $(50.0 \%)$ and most of the respondents were obedient in visiting the posyandu, namely as many as 21 respondents $(70.0 \%)$. The results of data analysis using Chi Square statistical test obtained $\mathrm{P}$ value $<0.05(0.000<0.05)$ which means that there is a relationship between maternal anxiety level and compliance with toddler visits to Integrated Service Post at Post of Public Health Center Tangkiang, Kintom District, Banggai Regency.

Conclusion : Mild mother's anxiety level can affect the compliance of toddlers' visits to posyandu during the Covid 19 pandemic.
\end{abstract}

Keywords: Anxiety level, toddler visits to integrated service post

Copyright @ 2021 IIK STRADA Indonesia All right reserved.

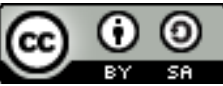

This is an open-acces article distributed under the terms of the Creative Commons AttributionShareAlike 4.0 International License. 


\section{INTRODUCTION}

Integrated Service Post or abbreviated Posyandu is a form of Community-Based Health Efforts (UKBM) which is managed and organized from, by, for and with the community in the implementation of health development in order to empower the community and provide convenience to the community in obtaining basic health/basic social services for accelerate the reduction of Maternal Mortality Rate and Infant Mortality Rate. (Ministry of Health RI, 2016)

Posyandu as an embodiment of community participation does not necessarily come and move by itself, government support for the existence and sustainability of Posyandu continues to be pursued. Various policies have been made, various activities and programs have been implemented to keep posyandu running and become the front gate of community empowerment. (Ministry of Health RI, 2016)

Until now, posyandu is still an important tool in the community that supports efforts to achieve Nutrition Awareness Families (KADARZI), helps reduce infant mortality and birth rates, and accelerates the acceptance of happy and prosperous small family norms. Activities include growth monitoring activities that are integrated with services such as immunization for disease prevention, diarrhea control, maternal and child health services, contraceptive services, to counseling and counseling. The main target of this posyandu activity is the entire community/family, especially newborns, infants, toddlers, breastfeeding mothers, postpartum mothers, and couples of childbearing age (PUS). (Ministry of Health RI, 2016)

The coverage of weighing children under five, both in Indonesia and in Indonesia, has decreased slightly. The coverage of weighing children under five in Indonesia in 2019 was $78.0 \%$, this coverage is lower than 2018 which was $80.8 \%$ (Ministry of Health RI, 2019).

Central Sulawesi Province from 2015 to 2018 experienced a not too significant upward trend from year to year, but in 2019 it experienced a very significant decline, where in 2015 it was $69.4 \%$, in 2016 it was $71.1 \%$, in 2017 was $71.9 \%$, and 2018 was $72.2 \%$, but in 2019 it decreased to $55.7 \%$. (Central Sulawesi Provincial Health Office 2019).

The coverage of visits to posyandu in Banggai district in 2019 of $17.9 \%$ is still far from the target set by the government (Banggai District Health Office 2019).

The coverage of posyandu visits at the Tangkiang Posyandu, Kintom District, Banggai Regency, which is $20 \%$, is still far from the specified target of $100 \%$ (Health Report at the Tangkiang Posyandu, 2020).

Based on the results of interviews conducted by researchers with 10 mothers, data was obtained that 6 mothers (70\%) who had toddlers were not obedient in visiting the Posyandu, this was due to the covid 19 pandemic. by covid 19 when visiting posyandu, while 4 mothers $(40 \%)$ under five were obedient in visiting posyandu. This is because mothers of toddlers assume that the implementation of posyandu is based on the health protocol set by the government, besides mothers of toddlers assume that visits to posyandu are very beneficial in addition to immunization of children, mothers can also know the growth and development of children and mothers also get additional insight. or information from outreach activities at the posyandu.

During the Covid-19 pandemic, posyandu services had stopped and the implementation of monitoring the growth and development of toddlers, posyandu services was carried out independently with the implementation model being handed over to each region according to the conditions or covid zones of each region. With the relaxation of activities during this pandemic (New Normal), posyandu activities in several areas have begun to be active again, but still their implementation must comply with the health protocol for psoyandu services issued by the government. One of them is posyandu in the regionPosyandu Tangkiang, Kintom District, Banggai Regencywhich is currently active for the implementation of posyandu services. The implementation of the posyandu must strictly comply with the health protocols that have been set because to minimize the risk of Covid-19 transmissionTo increase compliance with visits by mothers of children under five to Posyandu during the COVID-19 pandemic and reduce the level of anxiety of mothers bringing toddlers to Posyandu, it can be done by providing counseling and motivation to mothers participating in Posyandu and ensuring that the implementation of Posyandu is in accordance with the health protocols set by the government. the participation of cadres can be more active in providing information about posyandu activities during the pandemic by always implementing health protocols and telling what can be obtained from these posyandu activities. 
Based on the description above, the researcher is interested in conducting research on the analysis of maternal anxiety levels with compliance with toddler visits to the posyandu during the Covid 19 pandemic at the Tangkiang Posyandu, Kintom District, Banggai Regency.

\section{OBJECTIVE}

The purpose of this study was to analyze the level of mother's anxiety with the compliance of toddlers' visits to the Integrated Service Post during the Covid 19 pandemic at the Tangkiang Public Health Center, Kintom District, Banggai Regency.

\section{METHODS}

This study uses a correlational analytic design with a cross sectional approach. The population in this study were 30 respondents with a total sample of 30 respondents. sampling in this study using total sampling technique. Data collection using questionnaires and MCH handbooks. Data analysis to see the relationship between the independent variable and the dependent variable using the chi square statistical test with a significant level of $=0.05$

\section{RESULT \\ General data}

Table 4.1

Frequency distribution of respondents based on maternal age, education, occupation and parity

At the Tangkiang Posyandu, Kintom District, Banggai Regency

\begin{tabular}{|c|c|c|}
\hline Age & Frequency & Percentage (\%) \\
\hline$<20$ Years & 1 & 3.3 \\
\hline 20-30 Years & 11 & 36.7 \\
\hline$>30$ Years & 18 & 60.0 \\
\hline Amount & 30 & 100 \\
\hline Education & Frequency & Percentage (\%) \\
\hline SD & 6 & 20.0 \\
\hline junior high school & 3 & 10.0 \\
\hline senior High School & 20 & 66.7 \\
\hline PT & 1 & 3.3 \\
\hline Amount & 30 & 100 \\
\hline Work & Frequency & Percentage (\%) \\
\hline IRT & 29 & 96.7 \\
\hline Private & 0 & 0 \\
\hline entrepreneur & 0 & 0 \\
\hline civil servant & 1 & 3.3 \\
\hline Amount & 30 & 100 \\
\hline parity & Frequency & Percentage (\%) \\
\hline Primipara & 6 & 20.0 \\
\hline Multipara & 20 & 66.7 \\
\hline Grandemulti & 4 & 13.3 \\
\hline Amount & 30 & 100 \\
\hline
\end{tabular}

Based on table 4.1, it is found that most of the respondents aged $>30$ years are 18 respondents $(60.0 \%)$, most of the respondents have high school education as many as 20 respondents (66.7\%), almost all respondents do not work (IRT) as many as 29 respondents (96.7\%) and most of the respondents were multipara parity as many as 20 respondents $(66.7 \%)$. 
Table 4.2

Frequency distribution of respondents based on anxiety level at the Tangkiang Posyandu, Kintom District, Banggai Regency

\begin{tabular}{cccc}
\hline No & Anxiety Level & Frequency & Percentage (\%) \\
\hline 1 & No Worry & 9 & 30.0 \\
2 & Light & 15 & 50.0 \\
3 & Currently & 3 & 10.0 \\
4 & Heavy & 3 & 10.0 \\
\hline & Amount & 30 & 100 \\
\hline
\end{tabular}

Based on table 4.2, it was found that half of the respondents experienced a mild level of anxiety, namely 15 respondents $(50.0 \%)$.

\section{Toddler Visits Compliance to Posyandu}

Table 4.3

Frequency distribution of respondents based on Toddler Visits Compliance to Posyandu At the Tangkiang Posyandu, Kintom District, Banggai Regency

\begin{tabular}{cccc}
\hline No & Compliance Visits to Posyandu & Frequency & Percentage (\%) \\
\hline 1 & Obey & 21 & 70.0 \\
2 & Not obey & 9 & 30.0 \\
\hline & Amount & 30 & 100 \\
\hline
\end{tabular}

Based on table 4.3, it was found that most of the respondents complied with visiting posyandu as many as 21 respondents $(70.0 \%)$.

\section{Cross Tabulation Mother's Anxiety Level With Toddler Visits Compliance To Posyandu During the Covid 19 Pandemic}

Table 4.4

Cross Tabulation Mother's Anxiety Level With Toddler Visit Compliance

At the Tangkiang Posyandu, Kintom District, Banggai Regency

\begin{tabular}{lcccccc}
\hline \multirow{2}{*}{ Anxiety Level } & \multicolumn{4}{c}{ Visit Compliance } & \multicolumn{2}{c}{ Total } \\
\cline { 2 - 5 } & \multicolumn{2}{c}{ Obey } & \multicolumn{3}{c}{ Not obey } & \\
\cline { 2 - 5 } & $\mathrm{N}$ & $\%$ & $\mathrm{~N}$ & $\%$ & $\mathrm{~N}$ & $\%$ \\
\hline No Worry & 9 & 100 & 0 & 0 & 9 & 100 \\
Mild Anxiety & 12 & 80 & 3 & 20 & 15 & 100 \\
Moderate Anxiety & 0 & 0 & 3 & 100 & 3 & 100 \\
Heavy Anxiety & 0 & 0 & 3 & 100 & 3 & 100 \\
\hline \multicolumn{1}{c}{ Amount } & 21 & 70.0 & 9 & 30.0 & 30 & 100 \\
\hline
\end{tabular}

Based on table 4.5, it was found that out of 30 respondents, almost all respondents experienced mild anxiety levels and were obedient in visiting children under five to the posyandu during the COVID19 pandemic, as many as 12 respondents $(80.0 \%)$.

Statistical Test Results Relationship between Mother's Anxiety Levels with Toddler Visits Compliance to Posyandu During the Covid 19 Pandemic 
Table 4.5

Relationship statistical test resultsMother's Anxiety Levels with Toddler Visits Compliance at Posyandu at the Tangkiang Posyandu, Kintom District, Banggai Regency

\section{Chi-Square Tests}

\begin{tabular}{|c|c|c|c|}
\hline & Value & df & $\begin{array}{l}\text { asymp. Sig. (2- } \\
\text { sided) }\end{array}$ \\
\hline Pearson Chi-Square & $18,571 \mathrm{a}$ & 3 & .000 \\
\hline Likelihood Ratio & 21,640 & 3 & .000 \\
\hline Linear-by-Linear Association & 15.536 & 1 & .000 \\
\hline $\mathrm{N}$ of Valid Cases & 30 & & \\
\hline
\end{tabular}

a. 6 cells $(75.0 \%)$ have expected count less than 5. The minimum expected count is .90 .

Correlations

\begin{tabular}{|c|c|c|c|}
\hline & & Anxiety_Level & $\begin{array}{l}\text { Visit_To } \\
\text { Posyandu }\end{array}$ \\
\hline \multirow[t]{3}{*}{ Anxiety_Level } & $\begin{array}{l}\text { Pearson } \\
\text { Correlation }\end{array}$ & 1 & $.732 * *$ \\
\hline & Sig. (2-tailed) & & .000 \\
\hline & $\mathrm{N}$ & 30 & 30 \\
\hline \multirow[t]{3}{*}{ Visit_To Posyandu } & $\begin{array}{l}\text { Pearson } \\
\text { Correlation }\end{array}$ & $.732 * *$ & \\
\hline & Sig. (2-tailed) & .000 & \\
\hline & $\mathrm{N}$ & 30 & 30 \\
\hline
\end{tabular}

**. Correlation is significant at the 0.01 level (2-tailed).

Based on data analysis using statistical testsChi Square get value P value $<0.05(0.00<0.05)$, then $\mathrm{HO}$ is rejected and $\mathrm{H} 1$ is accepted, which means that there is a relationship between the level of maternal anxiety and compliance with toddler visits to the Posyandu during the Covid 19 Pandemic at Posyandu Tangkiang, Kintom District, Banggai Regency.

In addition, from the data analysis, the strength of the relationship between the independent and dependent variables had a strong relationship between the level of mother's anxiety and the compliance of toddlers' visits to the posyandu during the covid 19 pandemic at the Tangkiang Posyandu, Kintom District, Banggai Regency with a value of 0.732 because it was located between $0.50-0,75$.

\section{DISCUSSION}

Mother's Anxiety Level

Based on table 4.2 above, it is found that from 30 respondents, half of the respondents experienced mild anxiety levels, namely 15 respondents $(50.0 \%)$ who were not anxious as many as 9 respondents $(30.0 \%)$, who experienced moderate anxiety as many as 3 respondents $(10 \%)$ and who experienced severe anxiety as many as 3 respondents $(10 \%)$

Anxiety is an individual response to an unpleasant situation and is experienced by all living things in everyday life. Anxiety is a subjective experience of the individual and cannot be observed directly and is an emotional state without a specific object. Anxiety in individuals can provide motivation to achieve something and is an important source in an effort to maintain a balance of life (Suliswati, 2016).

The level of anxiety in the mothers of participants at the Tangkiang Posyandu is mostly mild anxiety, anxiety is a general feeling that can be felt by everyone when dealing with threatening situations (Stonerock, 2015), especially the current situation, many respondents who experiencing mild anxiety can be influenced by several things, including the activeness of posyandu cadres in providing information about Covid-19 and health workers who always remind about health protocols that must be obeyed when carrying out posyandu. 
The anxiety felt by respondents at Posyandu during this pandemic is if they catch Covid-19 from health workers or other posyandu visitors. The anxiety that is felt is natural because until now the Covid19 number has not been resolved, but for the implementation of the posyandu in several places, especially in the Tangkiang Posyandu, it has gone well because the implementation of the posyandu at the Tangkiang Posyandu is in accordance with government directives as outlined in the guidebook. Health services for toddlers published by the Indonesian Ministry of Health, so that mothers and toddlers feel safe from Covid-19

\section{Toddler Visits Compliance to Posyandu}

Based on table 4.3 above, it is found that from 30 respondents, most of the compliant respondents made visits to posyandu as many as 21 respondents $(70.0 \%)$ and those who complied made visits to posyandu as many as 9 respondents $(30.0 \%)$.

Compliance Posyandu visits are compliance visits made by mothers to weigh their babies or toddlers. The best toddler visits to posyandu are regularly every month or 12 times a year. For this reason, toddler visits are limited to 8 times per year. Posyandu whose frequency of weighing or visiting toddlers is less than 8 times per year is considered vulnerable. If the frequency of weighing has been 8 or more times in a period of one year it is considered good enough, but the frequency of weighing depends on the type of posyandu (Kemenkes RI, 2016).

The level of compliance in posyandu visits from the results of the study showed that most of the respondents were obedient in implementing posyandu during the pandemic period from July to August 2021, according to Niven (2016) that compliance is the extent to which a person's behavior is in accordance with the provisions, if according to researchers the respondent's compliance In conducting posyandu visits during the pandemic, it is supported by several factors such as the motivation of cadres, information about health protocols and also the need for monitoring of child growth and development by health workers.

\section{Relationship between Mother's Anxiety Levels with Toddler Visits Compliance to Posyandu During the Covid 19 Pandemic}

The results showed that from 30 respondents, almost all respondents experienced mild anxiety levels and were obedient in visiting children under five to the posyandu as many as 12 respondents $(80.0 \%)$.

Based on data analysis using Chi Square statistical test, it was obtained that $\mathrm{P}$ value $<0.05(0.000$ $<0.05)$, then $\mathrm{H} 0$ was rejected and $\mathrm{H} 1$ was accepted, which means that there is a relationship between the level of maternal anxiety and compliance with toddler visits to the Posyandu at Posyandu Tangkiang, Kintom District, proud.

The results showed that most of the respondents who experienced mild anxiety were obedient to visit children under five to the posyandu even though during the covid 19 pandemic this was due to the activeness of posyandu cadres in providing information about Covid-19 and health workers who always reminded about health protocols that must be obeyed when going to the hospital. implementing posyandu. posyandu participants have received motivation from cadres related to posyandu visits during the covid-19 pandemic, from the results of research conducted by Wiranti, et al (2020) which concluded that there is a relationship between motivation/support with adherence to health protocols with $\mathrm{p}$ value $=0.981$ when someone gets support then he will have a higher level of compliance,

This is also in accordance with the opinion of the results of a public survey conducted by the Alvara survey (2020) which concluded that during this pandemic period the public will experience panic and anxiety and with anxiety it will affect public behavior, especially health-related behavior. improved health such as wearing masks, washing hands, exercising, but there are also some declining health behaviors, such as being afraid to go to health services, afraid to seek treatment or being afraid to leave the house doing posyandu because they feel anxious if they catch Covid-19 from health workers. health or from visitors to other health services.with the implementation of the posyandu at the Tangkiang Posyandu in accordance with government directives as outlined in the guidebook for under-five health services published by the Indonesian Ministry of Health by implementing a health protocol so that mothers and toddlers feel safe from Covid-19, most of them also get good family support from their husbands. or parents about the importance of visiting posyandu even during a pandemic because it is to detect the growth and development of children, as long as when visiting they still apply health protocols, either by wearing masks, keeping a distance and so on.most also get good family support from their husbands or parents about the importance of visiting posyandu even during a pandemic because it is to 
detect the growth and development of children, as long as they continue to apply health protocols when visiting, whether by wearing masks, keeping a distance and so on.Most of them also get good family support from their husbands or parents about the importance of visiting posyandu even during a pandemic because it is to detect child growth and development, as long as when visiting, they still apply health protocols, either by wearing masks, keeping a distance and so on.

During a pandemic like the current one, everyone will feel anxious, especially the feeling of being infected with Covid-19, with this fear/anxiety, people will comply more with the health protocols required by the government. By maintaining vigilance against Covid-19 and coupled with compliance with health protocols, the risk of Covid-19 transmission can be avoided

\section{CONCLUSION}

1. Half of respondents di Posyandu Tangkiang, Kintom District, Banggai Regency experienced a mild level of anxiety as many as 15 respondents $(50.0 \%)$.

2. Most of the respondents in the Tangkiang Posyandu, Kintom District, Banggai Regency obediently visited the posyandu, namely 21 respondents $(70.0 \%)$.

3. There is a relationship between mother's level of anxiety and compliance with toddler visits to posyandu during the covid 19 pandemic at the Tangkiang Posyandu, Kintom District, Banggai Regency with a P value $<0.05(0.000<0.05)$ and a strong relationship strength with a value of 0.732

\section{REFERENCES}

1. Hidayat, A. (2016). Midwifery Research Methods and Data Analysis Techniques, Jakarta: Salemba Medika.

2. Hidayat A, Aziz Alimul. (2016). Midwifery Research Methods and Analysis Techniques. Salemba Medika. Jakarta

3. Indonesian Ministry of Health. (2020). Health Protocol.https://www.kemkes.go.id/article/ view/200316000003/Health-Protocol-COVID-19.html

4. Indonesian Ministry of Health. (2020). Guidelines for Toddler Health Services During the Covid-19 Pandemic Jakarta

5. Indonesian Ministry of Health. (2016). General Guidelines for Posyandu Management. Jakarta.

6. Indonesian Ministry of Health. (2016). Come To Posyandu Every Month. Jakarta

7. Indonesian Ministry of Health. (2020). Covid-19 prevention and control guidelines. Jakarta

8. Ismawati,. (2016). Posyandu and Desa Siaga. Noah Medika. Yogyakarta.

9. Niven, (2016). Educational and Health Psychology, Jakarta : EGC

10. Notoatmodjo, Soekidjo, (2016). Health Research Methods. Jakarta : Rineka Cipta.

11. Notoadmojo, Soekidjo. (2016). Health Promotion and Behavioral Science, Rineka Cipta. Jakarta

12. Nursalam, (2016). Concept and Application of Nursing Research Methodology. Jakarta: Salemba.

13. Sugiyono, (2016). Educational Research Methods Quantitative Approach. Qualitative, R\&D. Bandung.

14. Sulistiyaningsih. (2016). Midwifery Research Methodology.Yogyakarta: STIKes 'Aisyiyah Yogyakarta.

15. Alvara Survey, 2020. https://infobrand.id/survei-alvara-perlaku-publik-selama-pandemicovid-19.phtml.

16. Reni Puspita Sari, Uji Utami, (2020). The Relationship between Anxiety and Compliance in the Implementation of Health Protocols at Posyandu Malangjiwan Colomad Stethoscope VOL. 1 NO. 2 - DEC 2020. 